\title{
Characterization of the Clostridium pasteurianum Phosphotransferase System
}

\author{
By WILFRID J. MITCHELL ${ }^{1}$ AND IAN R. BOOTH ${ }^{2 *}$ \\ ${ }^{1}$ Department of Brewing and Biological Sciences, Heriot-Watt University, Chambers Street, \\ Edinburgh EH1 IHX, UK \\ ${ }^{2}$ Department of Microbiology, Marischal College, University of Aberdeen, \\ Aberdeen $A B 9$ IAS, UK
}

(Received 9 February 1984 ; revised 23 March 1984)

\begin{abstract}
The phosphoenolpyruvate-dependent glucose phosphotransferase system (PTS) of Clostridium pasteurianum was studied in toluene-treated cells and cell-free extracts. Toluene-treated cells phosphorylated the non-metabolizable glucose analogue methyl $\alpha$-glucoside in a PEP-dependent manner, and exhibited apparent $K_{\mathrm{m}}$ values of $93 \mu \mathrm{M}$ and $12 \mu \mathrm{M}$, respectively, for the substrates PEP and methyl $\alpha$-glucoside. Using cell-free extracts, it was shown that the system consists of both soluble and membrane-bound components. The rate of methyl $\alpha$-glucoside phosphorylation was dependent on the concentration of both the soluble and membrane fractions, and was independent of the concentration of PEP. Saturation kinetics for PEP were restored in the presence of a partially purified soluble fraction, which appeared to contain a single phosphotransferase component. This was similar to HPr of Escherichia coli by the following criteria: (i) it eluted in the same position from a Sephadex G-100 gel filtration column; (ii) it was relatively resistant to exposure to temperatures up to $100^{\circ} \mathrm{C}$; (iii) it was involved in phosphorylation of a number of sugars which enter the cell via different phosphotransferase systems; (iv) the kinetics of methyl $\alpha$-glucoside phosphorylation required the soluble protein in $C$. pasteurianum to be a substrate rather than an enzyme.
\end{abstract}

\section{INTRODUCTION}

The phosphoenolpyruvate:glucose phosphotransferase system is a widespread mechanism for carbohydrate accumulation by bacteria, particularly those which can grow under anaerobic conditions (Postma \& Roseman, 1976; Saier, 1977). Typically, as in the enteric bacteria Escherichia coli and Salmonella typhimurium, the system consists of a number of protein components which together constitute a phosphoryl transfer chain between the donor phosphoenolpyruvate (PEP) and the sugar substrate. The first two components, Enzyme I and $\mathrm{HPr}$, are cytoplasmic and are common to all the phosphotransferase systems (PTSs) in the cell; mutations affecting these proteins are thus pleiotropic, preventing growth on all PTS substrates. Enzyme I catalyses the phosphorylation of HPr by PEP, and is itself phosphorylated during the reaction; HPr then donates the phosphoryl group to the sugar in a process catalysed by a membrane-bound Enzyme II complex. The result is that the sugar is simultaneously phosphorylated and translocated across the cell membrane, and appears in the cytoplasm in derivatized form. The substrate specificity of each PTS is a property of the Enzyme II complex.

Few studies have been reported of the mechanism of carbohydrate transport in the genus Clostridium. Extracts of Clostridium thermocellum have been shown to contain PEP-dependent phosphotransferase activities for fructose and mannitol (Patni \& Alexander, 1971) and a fructose phosphotransferase has been found in a number of other species, including $C$.

Abbreviations: PEP, phosphoenolpyruvate; PTS, phosphotransferase system. 
pasteurianum (Hugo \& Gottschalk, 1974). In addition, cells of $C$. perfringens were shown to actively transport glucose and mannose by a single system which appeared to function by a phosphotransferase mechanism (Groves \& Gronlund, 1969). More recently, the mechanisms of carbohydrate transport in $C$. pasteurianum have been studied. Two carbohydrates, galactose and gluconate, were found to be taken up by a process driven by an electrochemical gradient of protons, apparently by a $\mathrm{H}^{+}$-symport mechanism (Booth \& Morris, 1975). On the other hand this organism was shown to possess distinct PEP-dependent PTSs for glucose, fructose and sucrose, and a single system for sorbitol and mannitol (Booth \& Morris, 1982). Furthermore, one class of mutants that was isolated as being resistant to 2-deoxyglucose, which is itself a substrate of the glucose PTS, showed a pleiotropic growth defect for the PTS sugars. This phenotypic property is shared by Enzyme I and HPr mutants of E. coli and $S$. typhimurium. It was concluded that $C$. pasteurianum possesses a range of PTSs which serve as the sole route of uptake of many fermentable sugars.

The present report extends the previous study in an investigation of the characteristics of the glucose PTS of $C$. pasteurianum. Using conventional techniques of cell disruption, the clostridial system was found to involve a soluble component, which had properties resembling those of $\mathrm{HPr}$ from $E$. coli and $S$. typhimurium; no evidence for a soluble Enzyme I component was found. The properties of the active component in soluble extracts of $C$. pasteurianum are discussed. Some of the results have been presented in preliminary form (Mitchell \& Booth, 1984).

\section{METHODS}

Strains, growth conditions and treatment of cells. Clostridium pasteurianum NCIB 9486 was maintained as a spore suspension in water at $4^{\circ} \mathrm{C}$. Samples were treated at $80^{\circ} \mathrm{C}$ for $10 \mathrm{~min}$, and allowed to grow out in $20 \mathrm{ml}$ reinforced clostridial medium (Oxoid) at $37^{\circ} \mathrm{C}$ for $18-20 \mathrm{~h}$. Portions $(5 \mathrm{ml})$ of this vegetatively growing culture were used to inoculate $400 \mathrm{ml}$ batches of defined salts and vitamins medium. The defined medium contained (per litre): $\mathrm{NH}_{4} \mathrm{Cl}, 3.0 \mathrm{~g} ; \mathrm{MgSO}_{4} .7 \mathrm{H}_{2} \mathrm{O}, 0.1 \mathrm{~g} ; \mathrm{NaCl}, 0.1 \mathrm{~g} ;\left(\mathrm{NH}_{4}\right)_{6} \mathrm{Mo}_{7} \mathrm{O}_{24} \cdot 4 \mathrm{H}_{2} \mathrm{O}, 0.01 \mathrm{~g} ; \mathrm{CaCl}_{2} .2 \mathrm{H}_{2} \mathrm{O}, 0.1 \mathrm{~g}$; $\mathrm{MnCl}_{2} .4 \mathrm{H}_{2} \mathrm{O}, 0.015 \mathrm{~g}$; FeNaEDTA, 0.275 g; biotin, $0.12 \mathrm{mg} ;$-aminobenzoic acid, $2 \mathrm{mg}$; glucose, $20 \mathrm{~g}$ (Mackey \& Morris, 1971). The pH was adjusted to $\mathbf{7 . 4}$ with $\mathbf{N a O H}$ and, after autoclaving, potassium phosphate buffer, $\mathrm{pH} 7$, was added to a concentration of $50 \mathrm{~mm}$. Growth was continued at $37^{\circ} \mathrm{C}$ for a further $18-20 \mathrm{~h}$, by which time the cultures had entered stationary phase. All growth vessels were sealed with Suba-seals, and the headspaces above the cultures were evacuated and filled with nitrogen. Cells were harvested by centrifugation $(10000 \mathrm{~g}$, $10 \mathrm{~min}$ ) at $4{ }^{\circ} \mathrm{C}$, washed with $50 \mathrm{~mm}$-potassium phosphate buffer, $\mathrm{pH} \mathrm{7,} \mathrm{and} \mathrm{resuspended} \mathrm{in} \mathrm{the} \mathrm{same} \mathrm{buffer.} \mathrm{For}$ experiments using toluene-treated cells, the wash buffer contained $0 \cdot 1 \%(w / v)$ L-cysteic acid. All growth media and wash buffers were rendered anaerobic by autoclaving immediately before use. Buffers were cooled under an atmosphere of oxygen-free nitrogen.

Cells were made permeable to low molecular weight solutes as follows. Toluene was added to an anaerobic cell suspension to a concentration of $0.3 \%(w / v)$, and the mixture was vortexed thoroughly for $20 \mathrm{~s}$ and incubated at $37^{\circ} \mathrm{C}$ for $20 \mathrm{~min}$. Cells were then stored on ice until used, for a maximum period of 3-4 h.

Escherichia coli K12 Fragl (thi-1 rha-4 lacz-82 gal-33) was supplied by Dr W. Epstein (University of Chicago, Chicago, Ill., USA) and strains 1101 (his-62 ptsHI relAl bglRII thi-1 $\lambda^{-}$spoTI) and ctr7 (ptsI7 relAl bglRI0 thi-1 $\lambda^{-}$) were obtained from the $E$. coli Genetic Stock Center, Yale University, USA. The strains were grown on L broth (Miller, 1972) containing $1 \%(w / v)$ glucose. Cells in late exponential phase were harvested and washed twice in $50 \mathrm{~mm}$-potassium phosphate buffer, $\mathrm{pH} 7$, containing $5 \mathrm{mM}-\mathrm{MgCl}_{2}$.

Preparation of cell-free extracts. Cells were resuspended in $50 \mathrm{~mm}$-potassium phosphate buffer, $\mathrm{pH} 7(4 \mathrm{ml}$ per $\mathrm{g}$ wet weight), and $\mathrm{MgCl}_{2}$ and dithiothreitol (DTT) were added to $5 \mathrm{~mm}$ and $1 \mathrm{~mm}$, respectively. The cells were disrupted by passage through a French pressure cell at $20000 \mathrm{lbf}^{-2}$ in $(138 \mathrm{MPa})$. Cell debris was removed by centrifugation at $12000 \mathrm{~g}$ for $10 \mathrm{~min}$, and the supernatant was used as crude extract. This crude extract was further fractionated into soluble extract and membrane by centrifugation at $175000 \mathrm{~g}$ for $90 \mathrm{~min}$. Membranes were washed once with $50 \mathrm{~mm}$-potassium phosphate buffer, $\mathrm{pH}$, containing $5 \mathrm{~mm}-\mathrm{MgCl}_{2}$ and $1 \mathrm{~mm}-\mathrm{DTT}$, and concentrated 10 -fold with respect to the original extract. The entire preparation was carried out at $4{ }^{\circ} \mathrm{C}$, and extracts were stored at $-20^{\circ} \mathrm{C}$. Phosphotransferase activity in extracts was unaffected by exposure to air, and so anaerobic techniques were not normally used after disruption of cells.

Fractionation of the soluble extract by gel filtration. Soluble extract was fractionated on a Sephadex G-100 column $(2.5 \times 50 \mathrm{~cm})$ at $8{ }^{\circ} \mathrm{C}$, in the presence of $5 \mathrm{~mm}-\beta$-mercaptoethanol at a flow rate of $18 \mathrm{ml} \mathrm{h}^{-1}$.

Assay of sugar phosphorylation. Phosphorylation of radiolabelled sugars by toluene-treated cells and cell-free extracts was routinely assayed in $50 \mathrm{~mm}$-potassium phosphate buffer, $\mathrm{pH} 7$, at $37^{\circ} \mathrm{C}$. Experiments were started by addition of the substrate after a 5 min preincubation period. For toluene-treated cells, incubation mixtures were supplemented with $4 \mathrm{mM}-\mathrm{MgCl}_{2}$ and $\mathrm{PEP}$ as required and the assays were carried out under a stream of nitrogen. 
For measurement of activity in extracts, assay mixtures contained $5 \mathrm{~mm}-\mathrm{MgCl}_{2}, 2 \mathrm{~mm}-\mathrm{DTT}, 12 \mathrm{mM}-\mathrm{NaF}$, and PEP. Samples $(0.1$ or $0.2 \mathrm{ml})$ were removed and sugar phosphate was precipitated in $2 \mathrm{ml}$ of a $1 \%(\mathrm{w} / \mathrm{v})$ solution of $\mathrm{BaBr}_{2}$ in $80 \%(\mathrm{v} / \mathrm{v})$ ethanol (Gachelin, 1969). The precipitate was trapped by filtration on Whatman GF/F filter discs, washed with $5 \mathrm{ml} 80 \%(\mathrm{v} / \mathrm{v})$ ethanol, and dried under a heat lamp. Radioactivity was determined in a Packard liquid scintillation spectrometer. Scintillant contained $6 \mathrm{~g}$ PPO and $75 \mathrm{mg}$ POPOP in 1 litre toluene.

Estimation of protein. The protein content of cell-free extracts was assayed by a microbiuret method (Zamenhof, 1957) using bovine serum albumin as standard.

Materials. Growth media were purchased from Oxoid. Phosphoenolpyruvate [tri(cyclohexylammonium) salt], DL-DTT, $d$-biotin and $p$-aminobenzoic acid, were obtained from Sigma. All other chemicals were of the highest purity commercially available. $\mathrm{D}-\left[\mathrm{U}-{ }^{14} \mathrm{C}\right] \mathrm{Glucose}$, methyl( $\left.\alpha-\mathrm{D}-\left[\mathrm{U}-{ }^{14} \mathrm{C}\right] \mathrm{gluco}\right)$ pyranoside, $\mathrm{D}-\left[\mathrm{U}-{ }^{14} \mathrm{C}\right] \mathrm{sorbitol}$, $\left[\mathrm{U}-{ }^{14} \mathrm{C}\right]$ sucrose, and $\mathrm{D}-\left[1{ }^{3} \mathrm{H}\right] \mathrm{galactose}$ were obtained from Amersham.

\section{RESULTS}

Properties of the phosphotransferase system of $C$. pasteurianum. Toluene-treated cells of $C$. pasteurianum have been shown to phosphorylate the non-metabolizable glucose analogue methyl $\alpha$-glucoside in a PEP-dependent manner via the glucose PTS (Booth \& Morris, 1982). The dependence of the rate of phosphorylation on the concentration of PEP and methyl $\alpha$-glucoside was examined (Fig. 1). The phosphorylation rate was found to be saturable by both substrates, and apparent $K_{\mathrm{m}}$ values measured were $93 \mu \mathrm{M}$ for PEP and $12 \mu \mathrm{M}$ for methyl $\alpha$-glucoside. Activity was optimal at $\mathrm{pH} \mathrm{7.5}$, and was increased in the presence of $\mathrm{Mg}^{2+}$, but showed no dependence on the concentration of the cation in the range 1 to $20 \mathrm{mM}$ (data not shown). Assays were routinely carried out at $\mathrm{pH} 7$, where the rate of methyl $\alpha$-glucoside phosphorylation was approximately $80 \%$ of the maximum.

PEP-dependent phosphorylation of methyl $\alpha$-glucoside was also demonstrated in crude extracts prepared from glucose-grown cells. The $K_{\mathrm{m}}$ for the sugar was identical to that found in the whole cell assay, indicating that the same mechanism is responsible for phosphorylation of methyl $\alpha$-glucoside in both experimental systems (Fig. 1a). However, the rate of methyl $\alpha$ glucoside phosphorylation in crude extracts showed no dependence on PEP concentration in the range $25 \mu \mathrm{M}$ to $1 \mathrm{mM}$ (Fig. 1 b). Thus it appears that a component (or components) of the PTS must have been diluted or inactivated during extract preparation to a point where it became limiting in the sugar phosphorylation assay. As the phosphorylation rate was independent of PEP concentration, this component was unlikely to be an enzyme activity. However, phosphotransferase mechanisms in other bacteria have been shown to involve low molecular weight proteins which behave as substrates for the enzymes of the system (Waygood et al., 1979; Beneski et al, 1982; Meadow \& Roseman, 1982).

Phosphorylation of methyl $\alpha$-glucoside by cell-free extracts required the participation of both soluble and membrane-bound components. Separation of crude extracts into soluble and membrane fractions resulted in loss of activity, which could be restored by mixing the separate fractions. Activity in the reconstituted assay system was found to be proportional to the amount of both soluble extract and membranes added (Fig. 2). This result cannot be explained on the basis of each fraction contributing only an enzyme activity to the overall reaction. However, it is consistent with the presence in the soluble extract of a sub-saturating concentration of a substrate for a membrane-bound enzyme. Such a component would be equivalent to HPr or

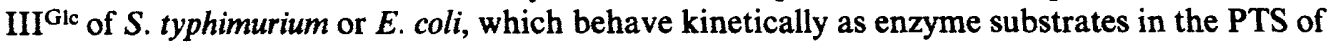
those organisms.

Fractionation of the soluble extract. The soluble extract was fractionated by gel filtration on a Sephadex G-100 column. When the eluate was tested for its ability to complement membranes in the methyl $\alpha$-glucoside phosphorylation assay, a single peak of activity was found which eluted with a $V_{\mathrm{e}} / V_{0}$ value of $2 \cdot 3$ to $2 \cdot 5$. When a soluble extract from $E$. coli $\mathrm{K} 12$ Frag1 (pts ${ }^{+}$) was subjected to gel filtration under the same conditions, none of the fractions obtained were capable of complementing $E$. coli membranes in methyl $\alpha$-glucoside phosphorylation. However, two soluble components, Enzyme I $\left(V_{\mathrm{e}} / V_{0}=1\right.$ to 1.6$)$ and $\mathrm{HPr}\left(V_{\mathrm{e}} / V_{0}=2.4\right.$ to 3$)$, were identified by their complementation of crude extracts prepared from ptsI (enzyme I-deficient) and pts $H$ ( $\mathrm{HPr}$ deficient) mutants, respectively. Thus the phosphotransferase components from $E$. coli and $C$. 

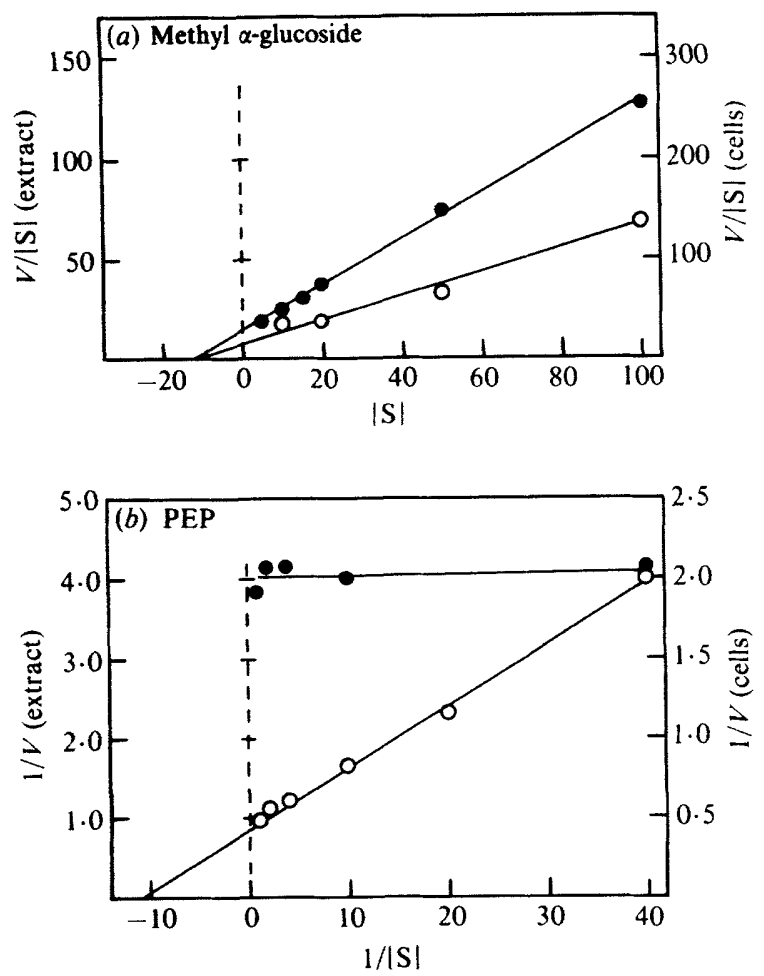

Fig. 1. Kinetics of phosphorylation of methyl $\alpha$-glucoside by toluene-treated cells and crude extracts of C. pasteurianum. Preparation of extracts, toluene treatment of cells, and assay of methyl $\alpha$-glucoside phosphorylation are described in Methods. In all cases, the assay volume was $1.0 \mathrm{ml}$, and $0.2 \mathrm{ml}$ samples were taken for estimation of methyl $\alpha$-glucoside phosphate. (a) Determination of $K_{\mathrm{m}}$ for methyl $\alpha$-glucoside: plot of $V /[\mathbf{S}]$ against [S]. The units of $V$ (rate of phosphorylation) are nmol $\mathrm{min}^{-1}$ (mg protein) ${ }^{-1}$; the units of $[S]$ (methyl $\alpha$-glucoside concentration) are $\mu \mathrm{M}$. Assay mixtures contained $0.5 \mathrm{mM}-\mathrm{PEP}$ and either $2.2 \times 10^{8}$ cells $(O)$ or $2.55 \mathrm{mg}$ extract protein (O). Specific activity of methyl $\alpha$ $\left[{ }^{14} \mathrm{C}\right.$ glucoside ranged from $5 \mathrm{mCi} \mathrm{mmol}^{-1}$ when the glucoside was present at concentrations below $50 \mu \mathrm{M}$ to $1 \mathrm{mCi} \mathrm{mmol}^{-1}$ at concentrations of $50 \mu \mathrm{M}$ and above. Rates of phosphorylation were determined from samples taken over a $5 \mathrm{~min}$ period after the addition of isotope. (b) Determination of $K_{\mathrm{m}}$ for PEP: plot of $1 / V$ against [S]. The units of $V$ (rate of phosphorylation) are nmol $\mathrm{min}^{-1}$ (mg protein $)^{-1}$; the units of [S] (PEP concentration) are mM. Assay mixtures contained $0 \cdot 1$ mM-methy] $\alpha$ $\left[{ }^{14} \mathrm{Clglucoside}\left(0.5 \mathrm{mCi} \mathrm{mmol}^{-1}\right)\right.$ and either $2.5 \times 10^{8}$ cells $(O)$ or $1.94 \mathrm{mg}$ extract protein $(O)$. Rates of phosphorylation were determined over a $5 \mathrm{~min}$ period for toluene-treated cells, and $10 \mathrm{~min}$ for crude extracts.

pasteurianum are clearly different in that the clostridial soluble fraction contains a single phosphotransferase component. This component elutes in a similar position to the $\operatorname{HPr}$ of $E$. coli.

Properties of the active soluble component. The heat stability of the soluble component was examined (Fig. 3). Even after boiling for $5 \mathrm{~min}$, appreciable activity remained in the soluble fraction. In contrast, the membrane-bound component(s) of the PTS were completely inactivated by brief incubation at $65^{\circ} \mathrm{C}$. The activity of the soluble fraction was destroyed by treatment with trypsin for $18 \mathrm{~h}$ at $37^{\circ} \mathrm{C}$ (data not shown). Therefore, taking these results in conjunction with the behaviour in gel filtration, it appears that the active component of the soluble fraction is a protein with properties resembling those of $\mathrm{HPr}$ in $S$. typhimurium and E. coli (Beneski et al., 1982; Kundig et al., 1964).

The ability of the soluble factor to participate in phosphorylation of sugars other than methyl $\alpha$-glucoside was examined. The Sephadex G-100 profile was the same whether the sugar used in the phosphorylation assay was methyl $\alpha$-glucoside, glucose, sucrose, or sorbitol (data not shown). 


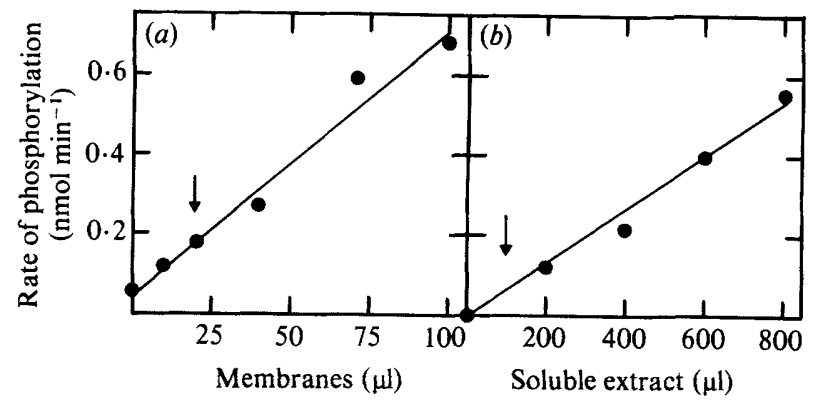

Fig. 2

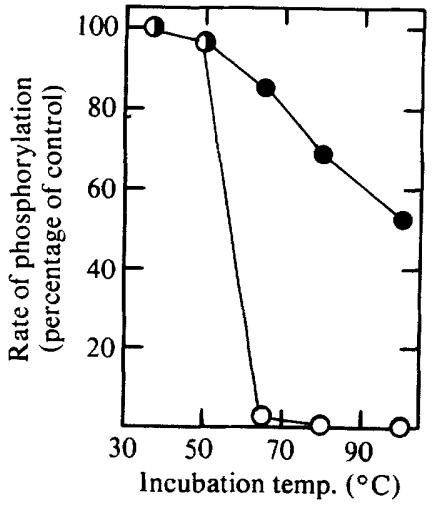

Fig. 3

Fig. 2. Phosphorylation of methyl $\alpha$-glucoside by extracts of $C$. pasteurianum. Crude extracts were fractionated into soluble and membrane-bound components, and phosphorylation of methyl $\alpha$ glucoside was assayed as described in Methods. Assay mixtures (total volume $1.0 \mathrm{ml}$ ) contained $0.25 \mathrm{~mm}$-PEP and $0.1 \mathrm{mM}$-methyl $\alpha-\left[{ }^{14} \mathrm{Clglucoside}\left(1 \mathrm{mCi} \mathrm{mmol}^{-1}\right)\right.$. Samples of $0.2 \mathrm{ml}$ were taken for estimation of methyl $\alpha$-glucoside phosphate. Rates of phosphorylation were determined over a 5 min period after the addition of isotope. ( $a$ ) Dependence of activity on concentration of membranes. Assays were carried out in the presence of $200 \mu \mathrm{l}(2.0 \mathrm{mg}$ protein) soluble extract. (b) Dependence of activity on concentration of soluble extract. Assays were carried out in the presence of $10 \mu \mathrm{l}(0.33 \mathrm{mg}$ protein) of membranes. The arrows indicate the point at which the relative amounts of soluble extract and membranes are equivalent to whole crude extract.

Fig. 3. Heat stability of $C$. pasteurianum soluble factor. Samples of $C$. pasteurianum soluble factor ( $O$; after passage through a Sephadex G-100 column) and membranes (O) were treated for $5 \mathrm{~min}$ at the indicated temperature, and assayed for phosphorylation of methyl $\alpha$-glucoside in the presence of untreated membranes and soluble factor, respectively, as described in Methods. Assay mixtures (total volume $1.0 \mathrm{ml})$ contained $0.5 \mathrm{mM}-\mathrm{PEP}, 50 \mu \mathrm{M}$-methyl $\alpha-\left[{ }^{14} \mathrm{C}\right] \mathrm{glucoside}\left(1 \mathrm{mCi} \mathrm{mmol}{ }^{-1}\right), 450 \mu \mathrm{l}$ (approx. $20 \mu \mathrm{g}$ protein) soluble factor and $0.87 \mathrm{mg}$ membrane protein. Samples of $0.2 \mathrm{ml}$ were taken for estimation of methyl $\alpha$-glucoside phosphate. Rates of phosphorylation were determined over a $60 \mathrm{~min}$ period after the addition of isotope. The $100 \%$ values were 1.93 and $1.48 \mathrm{nmol} \mathrm{h}^{-1}$ for soluble factor and membrane, respectively.

While the first two are substrates of the same PTS, the others have been shown to be phosphorylated by independent mechanisms (Booth \& Morris, 1982). In the case of sorbitol, it was necessary to use membranes prepared from sorbitol-grown cells, since those from glucosegrown cells were inactive in sorbitol phosphorylation. The soluble protein was thus common to each of the PTSs of $C$. pasteurianum. It was not however, involved in phosphorylation of galactose (data not shown). The galactose-phosphorylating activity of crude extracts of galactose-grown cells was not recovered by using a combination of membranes from these cells and the G-100 eluate.

The peak fractions from the Sephadex G-100 column were pooled, dialysed overnight against $10 \mathrm{~mm}$-Tris/ $\mathrm{HCl}$ buffer, $\mathrm{pH} 7 \cdot 5$, and concentrated 40 -fold by lyophilization. The concentrated material was found to saturate membranes in the methyl $\alpha$-glucoside phosphorylation assay (Fig. $4 a$ ). Under conditions in which the soluble factor was saturating, the rate of phosphorylation of methyl $\alpha$-glucoside was dependent on the concentration of PEP, with an apparent $K_{\mathrm{m}}$ value of $90 \mu \mathrm{M}$ (Fig. $4 b$ ). It was thus evident that the soluble fraction of extracts from $C$. pasteurianum contained a protein, at low concentration, which limited the rate of PEP-dependent sugar phosphorylation by limiting the flow of phosphate from PEP to the sugar substrate. Such a protein would have to fulfil the role of a substrate rather than an enzyme, and was thus functionally equivalent to HPr of $E$. coli and $S$. typhimurium.

Preliminary analysis of the peak fractions from the Sephadex G-100 column by SDSpolyacrylamide gel electrophoresis implicated a protein of approximate molecular weight 14000 as the soluble component of the PTS. 

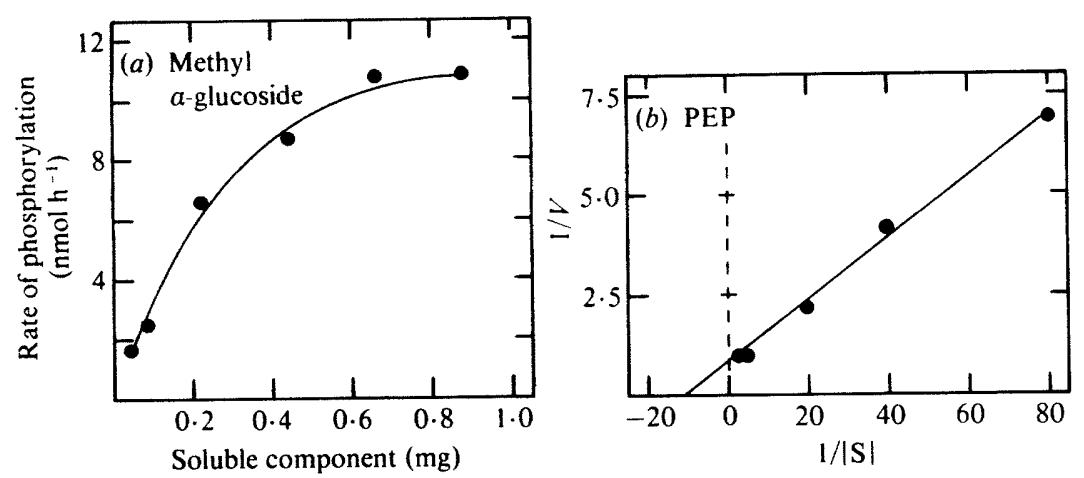

Fig. 4. (a) Saturation of membranes by concentrated soluble factor. The peak fractions from Sephadex G-100 chromatography were pooled and concentrated, and phosphorylation of methyl $\alpha$-glucoside was assayed as described in Methods. Assay mixtures (total volume $0.75 \mathrm{ml}$ ) contained membranes $(0.45 \mathrm{mg}$ protein), $0.5 \mathrm{mM}$-PEP, $50 \mu \mathrm{M}$-methyl $\alpha-{ }^{14} \mathrm{Clglucoside}\left(9.66 \mathrm{mCi} \mathrm{mmol} \mathrm{m}^{-1}\right)$, and soluble factor as indicated. Samples of $0.1 \mathrm{ml}$ were taken for estimation of methyl $\alpha$-glucoside phosphate. Rates of phosphorylation were determined over periods of 10 to $30 \mathrm{~min}$ after the addition of isotope depending on the soluble factor concentration. (b) Determination of $K_{\mathrm{m}}$ for PEP in methyl $\alpha$-glucoside phosphorylation by extracts of $C$. pasteurianum: plot of $1 / V$ against $1 /[\mathrm{S}]$. The units of $V$ (rate of phosphorylation) are nmol $\mathrm{min}^{-1}$ (mg protein) ${ }^{-1}$; the units of [S] (PEP concentration) are mM. Methyl $\alpha$-glucoside phosphorylation was assayed as described in $(a)$. Assay mixtures contained $1.1 \mathrm{mg}$ soluble factor.

Cross-reaction with other bacterial PTSs. Antisera to S. typhimurium HPr, Enzyme I and $\mathrm{III}^{\mathrm{Glc}}$, E. coli HPr and Enzyme I, and to Staphylococcus aureus HPr did not cross-react with $C$. pasteurianum extracts in Ouchterlony immuno-diffusion assays (data not shown).

\section{DISCUSSION}

In common with other obligate and facultative anaerobes, $C$. pasteurianum accumulates a number of sugars by a PEP-dependent PTS mechanism (Booth \& Morris, 1982). This report extends earlier results to examine some of the properties of the glucose PTS in C.pasteurianum. As for the PTSs of other organisms, both soluble and membrane-bound components are involved. However, while most phosphotransferase mechanisms require the participation of two soluble proteins, Enzyme I and HPr, the clostridial system appears to be dependent on a single soluble component.

When $E$. coli extracts were subjected to the same extraction and chromatographic procedure, the Enzyme I and HPr proteins were soluble and were separated as previously reported (Postma $\&$ Roseman, 1976). Thus there was a clear difference between the two organisms in this respect. The active soluble component of the $C$. pasteurianum PTS behaves like the HPr of $E$. coli in gel filtration, and in addition, the two proteins shared the properties of stability to short exposure to high temperature, and participation in each of the PTSs of the organism. This protein was not involved in phosphorylation of galactose and this observation is consistent with the earlier demonstration that galactose is not a PTS substrate in C. pasteurianum (Booth \& Morris, 1975, 1982).

Bacterial PTSs exhibit a remarkable degree of uniformity. In most cases the two common components, Enzyme I and HPr, are found in soluble form in cell-free extracts. The location of these proteins is, however, different in some cases. In Ancalomicrobium adetum, both were found to be tightly associated with the membrane (Saier \& Staley, 1977) while the fructose-specific PTS of Rhodopseudomonas sphaeroides contained a large membrane-associated enzyme (SF) which could be isolated in soluble form and appeared to be functionally equivalent to Enzyme I of $E$. coli (Robillard et al., 1979); in the latter organism an HPr-like protein has not been found, although its existence as part of the SF molecule was inferred. The single clostridial component 
identified so far differs from the SF protein by virtue of its low molecular weight and the fact that its properties are not consistent with an enzyme activity. If $C$. pasteurianum contains an Enzyme I of similar size to that of other bacteria it must remain tightly associated with the membrane during extraction.

The Enzyme I of $E$. coli has been shown to possess extremely hydrophobic surface regions (Brouwer et al., 1982) and to form a functional complex with HPr and Enzyme II on the membrane (Saier et al., 1982). Thus, it is conceivable that a similar complex might be formed on the clostridial membrane, resulting in a more effective transport system. At present, however, there is no evidence for an Enzyme I component in C. pasteurianum.

Finally, previous work with $C$. thermocellum led to the suggestion that the low level of PTS activity in extracts was not sufficient to explain the rates of fructose and mannitol flux necessary for growth (Patni \& Alexander, 1971). From our study it is clear that due to the dilution of PTS components during extraction the rates of phosphorylation observed are approximately 10-fold lower than those in toluene-treated cells. Thus, the latter system provides a more reliable guide to the potential of the system to act as a route of carbon uptake during growth.

The authors would like to express their gratitude to the following: Dr N. A. Booth for performing gel filtration and polyacrylamide gel electrophoresis; Professor S. Roseman, Dr G. Robillard and Professor W. Hengstenberg for antisera and purified phosphotransferase proteins; Dr B. J. Bachmann for $E$. coli strains from the $E$. coli Genetic Stock Center. The work was funded by SERC grant no. GRB 95493.

\section{REFERENCES}

Beneski, D.A., Nakazawa, A., Weigel, N., HartMaN, P. E. \& Roseman, S. (1982). Sugar transport by the bacterial phosphotransferase system - isolation and characterization of a phosphocarrier protein HPr from wild-type and mutants of Salmonella typhimurium. Journal of Biological Chemistry 257, 14492-14498.

BOOTH, I. R. \& MorRis, J. G. (1975). Protonmotive force in the obligately anaerobic bacterium Clostridium pasteurianum - a role in galactose and gluconate uptake. FEBS Letters 59, 153-157.

BOOTH, I. R. \& MORRIS, J. G. (1982). Carbohydrate transport in Clostridium pasteurianum. Bioscience Reports 2, 47-53.

Brouwer, M., Elferinck, M. G. L., \& Robillard, G. T. (1982). Phosphoenolpyruvate-dependent fructose phosphotransferase system of Rhodopseudomonas sphaeroides: purification and physicochemical and immunochemical characterization of a membrane associated enzyme I. Biochemistry 21, 82-88.

GACHELIN, G. (1969). A new assay of the phosphotransferase system in Escherichia coli. Biochemical and Biophysical Research Communications 34, 382387.

Groves, D. J. \& Gronlund, A. F. (1969). Carbohydrate transport in Clostridium perfringens. Journal of Bacteriology 100, 1256-1263.

Hugo, H. V. \& GotTschalK, G. (1974). Distribution of 1-phosphofructokinase and PEP : fructose phosphotransferase activity in clostridia. FEBS Letters 46, 106-109.

Kundig, W., Ghosh, S. \& Roseman, S. (1964). Phosphate bound to histidine in a protein as an intermediate in a novel phosphotransferase system. Proceedings of the National Academy of Sciences of the United States of America 52, 1067-1074.

MACKEY, B. M. \& MoRRIS, J. G. (1971). Ultrastructural changes during sporulation of Clostridium pasteurianum. Journal of General Microbiology 66, 113.

MEadow, N. D. \& Roseman, S. (1982). Sugar transport by the bacterial phosphotransferase system - isolation and characterization of a glucose-specific phosphocarrier protein (IIIGle) from Salmonella typhimurium. Journal of Biological Chemistry 257, 14526-14537.

MILLER, J. H. (1972). Experiments in Molecular Genetics, p. 433. Cold Spring Harbor, New York: Cold Spring Harbor Laboratory.

MrTCHELL, W. J. \& Booth, I. R. (1984). Phosphotransferase system of Clostridium pasteurianum. Biochemical Society Transactions 12, 239.

Patni, N. J. \& AleXander, J. K. (1971). Catabolism of fructose and mannitol by Clostridium thermocellum: presence of PEP: fructose phosphotransferase, fructose-1-phosphate kinase, PEP:mannitol phosphotransferase and mannitol-1-phosphate dehydrogenase in extracts. Journal of Bacteriology 105, 226231.

Postma, P. W. \& Roseman, S. (1976). The bacterial phosphoenolpyruvate phosphotransferase system. Biochimica et biophysica acta 457, 213-257.

ROBIllard, G. T., DOOIJEWAard, G. \& Lolkema, J. (1979). Escherichia coli phosphoenolpyruvate-dependent phosphotransferase system. Complete purification of Enzyme I by hydrophobic interaction chromatography. Biochemistry 18, 2984-2989.

SAIER, M. H., JR. (1977). Bacterial phosphoenolpyruvate:sugar phosphotransferase systems: structural, functional and evolutionary relationships. Bacteriological Reviews 41, 856-871.

SAIER, M. H., JR \& Staley, J. T. (1977). Phosphoenolpyruvate : sugar phosphotransferase system in Ancalomicrobium adetum. Journal of Bacteriology 131, 716718.

SAIER, M. H., JR, CoX, D. F., Feucht, B. U. \& 
Novotny, M. H. (1982). Evidence for functional association of Enzyme I and HPr of the phosphoenolpyruvate sugar phosphotransferase system with the membrane in sealed vesicles of Escherichia coli. Journal of Cellular Biochemistry 18, 231-238.

Waygood, E. B., Meadow, N. D. \& Roseman, S.
(1979). Modified assay procedure for the phosphotransferase system in enteric bacteria. Analytical Biochemistry 95, 293-304.

Zamenhof, S. (1957). Preparation and assay of deoxyribonucleic acid from animal tissue. Methods in Enzymology 3, 702. 